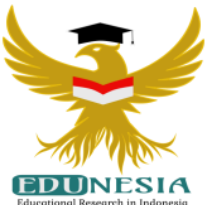

\title{
Improving Biology Learning Outcomes on Enzymes and its Functions Through Modification of Multiple Refresentation Learning Model in Class XII IPA SMAN 1 Danau Panggang
}

\author{
Noraini \\ Biology Education, SMAN 1 Danau Panggang Kab. HSU Kalimantan Selatan, Indonesia \\ Corresponding Email: norainihsu3@gmail.com, Phone Number: 0812 xxxx xxxx
}

Article History:

Received: Apr 19, 2021

Revised: May 28, 2021

Accepted: Jun 08, 2021

Online First: Jun 11, 2021

\section{Keywords:}

Completeness of Learning Outcomes, Modification,

Multiple Representations.

\section{Kata Kunci:}

Ketuntasan Hasil Belajar, Modifikasi, Multiple

Representasi.

\footnotetext{
How to cite:

Noraini, N. (2021). Improving Biology Learning Outcomes on Enzymes and its Functions Through Modification of Multiple Refresentation Learning Model in Class XII IPA SMAN 1 Danau Panggang. Edunesia: Jurnal Ilmiah Pendidikan, 2 (2): 569 575.
}

This is an open access article under the CC-BY-NC-ND license (c) $(\$) \ominus$
Abstract: The Biology learning process in class XII IPA at SMA Negeri 1 Danau Panggang has so far been more dominant in applying conventional learning models which are characterized by 1) teacher-centered, 2) emphasis on receiving knowledge, 3) less variety, 4) less empowerment of all potential students, and 5) using a monotonous method, because the teacher is dominant as the center of learning resources as a result, there are still many students who are passive, most students do not dare to ask questions. Student activity in learning and discussion is still low, many students in the learning process seem to be passive. As a result, learning becomes boring and less passionate, so learning outcomes are low. The purpose of this study was to improve learning outcomes of Biology on the subject of enzymes and their functions through Modification of the Multiple Representation Learning Model in class XII IPA SMAN 1 Danau Panggang. The research method used is comparative descriptive. Data were taken from 23 students with details of 8 men and 15 women. Then from the data, the percentage value of student learning completeness classically is sought using a predetermined formula using instruments in the form of observations of teacher activities, observations of student activities and student learning outcomes. The results of the final study showed that the average value obtained was 76.52 and the completeness of learning outcomes was $100 \%$. Meanwhile, the activities of teachers and students also increased. Teacher activity increased from $59.72 \%$ to $79 \%$ with criteria from good to very good. Student activity also increased from $48 \%$ to $65 \%$ with good criteria.

Abstrak: proses pembelajaran Biologi dikelas XII IPA SMA Negeri 1 Danau Panggang selama ini lebih dominan menerapkan model pembelajaran konvensional yang ditandai 1) berpusat pada guru, 2) penekanan pada menerima pengetahuan, 3) kurang bervariasi, 4) kurang memberdayakan semua potensi siswa, dan 5) menggunakan metode yang monoton, karena guru dominan sebagai pusat sumber pembelajaran akibatnya Masih banyak siswa yang pasif, Sebagian besar siswa tidak berani bertanya. Aktivitas siswa dalam belajar dan diskusi masih rendah, siswa dalam proses pembelajaran kelihatan masih banyak yang pasif. Akibatnya pembelajaran menjadi membosankan dan kurang bergairah, sehingga hasil belajar menjadi rendah. Tujuan penelitian ini adalah untuk meningkatkan hasil belajar Biologi pada pokok bahasan enzim dan fungsinya melalui Modifikasi Model Pembelajaran Multipel Representasi pada siswa kelas XII IPA SMAN 1 Danau Panggang. Metode penelitian yang gunakan adalah secara Diskriptif Kompratif. Data diambil dari siswa sebanyak 23 orang dengan rincian 8 orang pria dan 15 orang wanita. Kemudian dari data tersebut dicari nilai persentase ketuntasan belajar siswa secara klasikal mengunakan rumus yang sudah ditentukan menggunakan instrumen berupa hasil pengamatan aktivitas guru, pengamatan aktivitas siswa dan hasil belajar siswa. Hasil penelitian akhir menunjukkan bahwa nilai yang diperoleh rata-rata 76,52 dan ketuntasan hasil belajar 100\%. Sementara itu, aktivitas guru dan siswa juga meningkat. Aktivitas guru meningkat dari 59,72\% menjadi 79\% dengan kriteria dari baik menjadi sangat baik. Aktivitas siswa juga meningkat dari 48\% menjadi $65 \%$ dengan kriteria baik. 


\section{A. Introduction}

On learning outcomes in the biology learning process in class XII IPA SMA Negeri 1 Danau Panggang, this shows that student achievement is still low. This can be seen from the average value of the daily test results which are still below the minimum completeness criteria, which is 58.70 from minimum completeness criteria which is set at 65 . The lowest score is 40 and the highest score is 70 from 23 students. Only 5 people completed or $21.74 \%$, 18 people did not complete or $78.26 \%$ of the total number of students. This data proves that the achievement of student learning outcomes and learning activities is still low. Therefore, it is necessary to make efforts to increase the achievement of learning outcomes and student activities, as well as to improve the quality of researchers in their main task as educators.

The Biology learning process in class XII IPA SMA Negeri 1 Danau Panggang is generally more dominant in applying the conventional learning model which is characterized 1) teacher-centered, 2) emphasis on receiving knowledge, 3) less variety, 4) less empowering all potential students, and 5) using methods which is monotonous, because the teacher tends to be dominant as the center of learning resources as a result: There are still many students who are passive. Most of the students do not dare to ask questions. Student activity in learning and discussion is still low, many students in the learning process seem to be passive. As a result, learning becomes cold and less enthusiastic.

With the things mentioned above so that the learning process can become warmer, more passionate, learning achievement increases, it is necessary to look for a modern cooperative learning model in order to generate benefits for the development of logical thinking skills, critical attitudes and student sensitivity so that the overall learning process becomes better. cooperative and fun when compared to conventional learning models. Many cooperative learning models are available.

According to experts, there are many types of modern cooperative learning models, as mentioned by Hamdayama (2016) various learning models, including Project Based Learning, Quantum Learning, Multiple representations, Team Accelerated Instruction and many others.

The four examples of the learning model are modern, cooperative and studentcentered, this is different when compared to the conventional learning model which is only teacher-centered. From the results of research by Iswari (2018), it shows that when compared to the two, the average value of the cooperative learning model (Team Accelerated Instruction) is much higher than the conventional model, namely 95.8341 with 79.6875 . Another median value, namely the median is also much different in the conventional model, the median value is 79,1650 while the Cooperative model (Team Accelerated Instruction) is 100. Based on this explanation, it can be concluded that the cooperative learning model (Team Accelerated Instruction) can increase students' cognitive scores.

In connection with the above problems, the researchers tried to modify the multiplerepresentation learning model with the minimum hope of producing students who have an honest, disciplined attitude, opinion, respect friends, responsibility and achievement, so that ultimately will improve learning outcomes.

In an effort to achieve good learning outcomes, classroom action research (CAR) is very much needed to overcome the learning process that does not produce value and a fun learning process. There is a gap between expectations and reality in a test, where the results of learning biology in the pre-cycle mostly only reach scores below the minimum completeness criteria. 
So that learning outcomes can increase to reach the minimum completeness criteria or above, it is necessary to increase all activities in the biology learning process. One way is to conduct classroom action research in the form of a modified multiple representation learning model.

\section{B. Method}

The subjects of this study were students of class XII IPA SMAN 1 Danau Panggang. In the subject of this research, will produce products that come from 3 kinds of actions in the form of Pre-Cycle, Cycle I and Cycle II. The product of the research results in the form of cognitive assessment results, teacher and student activities. The place of this research is at SMAN 1 Danau Panggang, J1 Sukaramai RT.04, No.63 Kecamatan Danau Panggang. The number of students to be studied is 23 students of class XII IPA SMAN 1 Danau Panggang consisting of 8 men and 15 women. This research procedure consists of 3 cycles, each cycle consisting of 6 stages of the learning process, each of which is contained in a lesson plan.

In this study, the instruments used for data collection were observations, interviews, observations of teacher activities, observations of student activities, student worksheet/discussion summaries and test scores. Data analysis is carried out with the aim of

a. To determine student achievement, comparative descriptive analysis was used. Where to find the percentage of student learning completeness classically using the following formula:

Note:

$$
\%=\frac{\mathrm{n}}{\mathrm{N}} \times 100
$$

$\mathrm{n} \quad \quad=$ The number of students who scored $\geq 65$

$\mathrm{N} \quad=$ The total number of students

Value $<65=$ students did not complete their studies

Value $\geq 65=$ students complete their studies

(Muhidin \& Abdurahman, 2011).

b. Calculate the class average value with the formula:

Note:

$\mathrm{X}=$ Average (mean)

$$
\overline{\mathrm{X}}=\frac{\sum X}{N}
$$

$\sum \mathrm{X}=$ sum of all scores

$\mathrm{N} \quad=$ number of subjects

Sudjana (2010).

c. The results of the student activity observation sheet were analyzed in the following way:

$$
\mathrm{NP}=\frac{\mathrm{R}}{\mathrm{SM}} \times 100
$$

Note:

NP = Percent value sought

$\mathrm{R}=\quad=$ score obtained by students

$\mathrm{SM} \quad=$ ideal maximum score 
100

$=$ Fixed number

With the percentage value criteria used the following criteria:

$x \leq 25=$ Bad $(B)$

$25<x \leq 50=$ Fairly Good (FG)

$50<x \leq 75=\operatorname{Good}(\mathrm{G})$

$75<x \leq 100=$ Very Good (VG)

(Purwanto, 2010)

d. The results of the student activity observation sheet were analyzed by as follows:

$$
\mathrm{NP}=\frac{\mathrm{R}}{\mathrm{SM}} \times 100
$$

Note:

$\mathrm{NP}=$ Percent value sought

$\mathrm{R}=$ Score obtained by students

$\mathrm{SM}=$ Ideal maximum score

$100=$ Fixed number

With the percentage value criteria used the following criteria:

$\mathrm{X} \leq 25=\mathrm{Bad}(\mathrm{B})$

$25<x \leq 50=$ Fairly Good (FG)

$50<x \leq 75=$ Good $(G)$

$75<x \leq 100=$ Very Good $(V G)$

(Purwanto, 2010)

This success indicator includes the percentage of student learning outcomes, teacher activities and student activities. Learning outcomes are said to be successful if they meet the percentage of completeness $65 \%$. Teacher activities and student activities are said to be successful if they meet the percentage of $50 \%<x 75 \%=$ Good $(G)$ or $75 \%<x 100 \%=$ Very Good (VG).

\section{Result and Discussion}

From several tables and graphs, the summary of the research results below, starting from the pre-cycle, the first cycle of action, the second cycle and up to the third cycle of action. Tables and graphs consist of a summary table listing student learning outcomes, a summary of student activity observations, a summary of teacher activity observations and a summary of the measurement of learning outcomes, teacher and student activities.

Table 1. The value of student learning outcomes

\begin{tabular}{ccccc}
\hline Category & $\begin{array}{c}\text { Pre-cycle } \\
\text { Value }\end{array}$ & $\begin{array}{c}\text { Cycle I } \\
\text { Value }\end{array}$ & $\begin{array}{c}\text { Cycle II } \\
\text { Value }\end{array}$ & $\begin{array}{c}\text { Cycle III } \\
\text { Value }\end{array}$ \\
\hline Average & 58,70 & 65,65 & 67,39 & 76,52 \\
Completeness & $21,74 \%$ & $30,43 \%$ & $86,96 \%$ & $100 \%$ \\
\hline
\end{tabular}


Table 2. Student activity observation results

\begin{tabular}{cccc}
\hline Category & $\begin{array}{c}\text { Cycle I } \\
\text { Value }\end{array}$ & $\begin{array}{c}\text { Cycle II } \\
\text { Value }\end{array}$ & $\begin{array}{c}\text { Cycle III } \\
\text { Value }\end{array}$ \\
\hline Average & 31 & 31 & 47 \\
Student activity & $48 \%$ & $59 \%$ & $65 \%$ \\
\hline
\end{tabular}

Table 3. Teacher activity observation results

\begin{tabular}{cccc}
\hline Category & $\begin{array}{c}\text { Cycle I } \\
\text { Value }\end{array}$ & $\begin{array}{c}\text { Cycle II } \\
\text { Value }\end{array}$ & $\begin{array}{c}\text { Cycle III } \\
\text { Value }\end{array}$ \\
\hline Average & 43 & 44 & 57 \\
Teacher activity & $59,72 \%$ & $62,12 \%$ & $79 \%$ \\
\hline
\end{tabular}

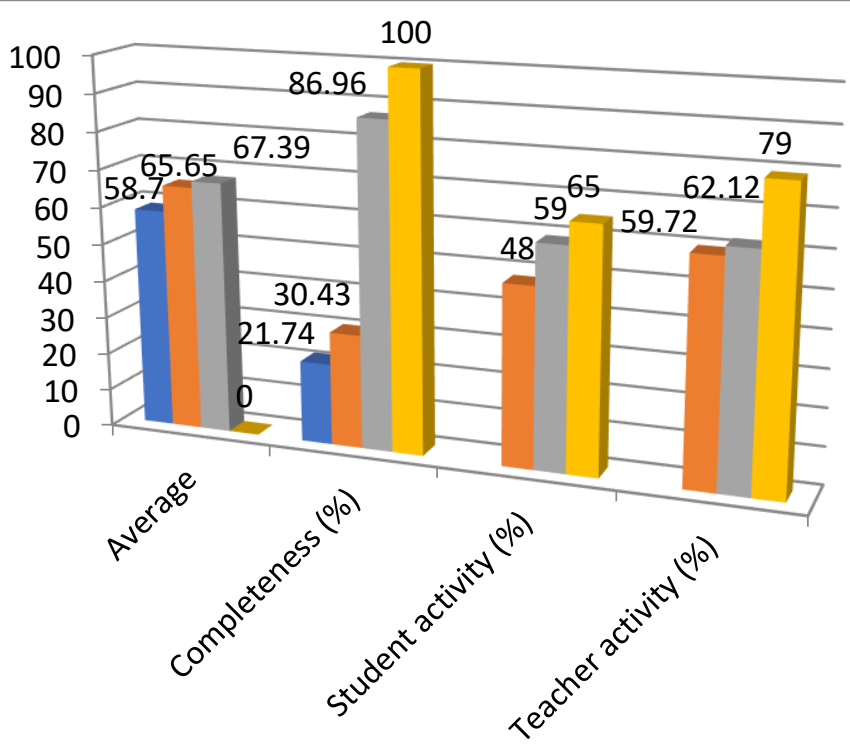

Pre-Cycle

- Cycle I

Cycle II

Cycle III

Figure 1. Learning outcomes, student and teacher activities

In the initial conditions the average value was 58.70 to 65.65 in cycle I, to 67.39 in the cycle II and to 76.52 in cycle III. Everything is calculated based on the value obtained by students from the lowest to the highest.

The lowest value of the pre-cycle condition was 40, at the end of the cycle the lowest value increased to 60 . While the highest value also increased from the pre-cycle condition was 70 at the end of the cycle action increased to 90.00. Students who have completed the pre-cycle increased from only 5 . In the final cycle to 23 people.

Based on teacher observation data, the process of teaching and learning activities went according to plan, all aspects could be implemented properly, such as the time used had not shifted far from the previously planned stages, there was time available in linking the material with other relevant knowledge, the quality of motivation at the beginning of the learning process has improved, and there is enough time to draw conclusions by involving students. Closing the lesson is no longer rushed, because there is time to pray well. All of these processes can run well, because they are supported by student activities that are getting better as well. 
According to Nashar (2010), learning motivation is the tendency of students to carry out learning activities that are driven by a desire to achieve the best possible achievement or learning outcomes. In a study on the scientific family by Doyan, et al. (2018) with the ANOVA test, it is concluded that there is an effect of the multiple representation learning approach and students' learning motivation on learning outcomes. Multi-representation is one way to increase external motivation.

The results of research on multiple representations by Widianingtiyasa, et al (2015) showed that students in the experimental class showed an increase in learning outcomes of $7.14 \%$ in the posttest. Meanwhile, students in the control class experienced an increase of $0.32 \%$. Thus, it can be seen that the increase in learning outcomes is greater in the experimental class so that it can be concluded that the multi-representation approach has a positive effect on students' cognitive abilities.

Mousavi and Sweller (2011) researched the reduction of cognitive load by mixing audio and visual presentation models. The results showed that various sources of information produce a large cognitive load, effective cognitive capacity can be increased when audio and visual are used.

The form of using audio and visual in this study is that students use power point applications in presenting the results of their discussions. In the power point application there are animations in the form of words, pictures and videos that can help students construct or build their knowledge to obtain higher learning outcomes. As explained by Mayer and Moreno (2010) researched animation instruction in teaching that can help students build relationships between words and pictures in multimedia learning, where the results show that students who get narrative explanations along with animation have higher scores than students who are given narration or amination only.

Thus modifying the Multiple Representation learning model assisted by the use of power point animations in the presentation of student discussion results can further improve biology learning outcomes, teacher and student activities on the subject of enzymes and their functions.

\section{Conclusion}

The conclusion of this study is that the results of the study indicate the initial condition of the class average value of 58.70 with the criteria of completeness learning outcomes of $21.74 \%$, with this value the criteria for completeness have not been achieved. The average value of the first cycle class is 65.65 with complete learning outcomes of $30.43 \%$, with this value, the criteria for completeness have not been achieved. The average value of the second cycle class is 67.39 with complete learning outcomes of $86.96 \%$, with this value the criteria for completeness can be categorized as achieved or successful. However, it is more convincing with the third cycle with an average grade of 76.52 and complete learning outcomes of $100 \%$. Meanwhile, the activities of teachers and students also increase. Teacher activity increased from $59.72 \%$ to $79 \%$ with the criteria categorized from good to very good. Student activity also increased from $48 \%$ to $65 \%$ with the criteria categorized from quite good to good. 


\section{References}

Doyan, A., Taufik, M., \& Anjani, R. (2018). Pengaruh pendekatan multi representasi terhadap hasil belajar fisika ditinjau dari motivasi belajar peserta didik. Jurnal Penelitian Pendidikan IPA, 4(1).

Hamdayama, J. (2016). Metodologi pengajaran. Jakarta: Bumi Aksara.

Iswari. (2018). Perbandingan Hasil Belajar Antara Model Pembelajaran Konvensional Dengan Model Pembelajaran Kooperatif Tipe Team Accelerated Instruction (TAI) Pada Mata Pelajaran Mekanika Teknik Kelas X Tgb Di Smk Negeri 2 Surakarta. https://eprints.uns.ac.id. Diakses 23 Mei 2020

Mayer, R. E. \& Moreno, R. (2002). Animation as an aid to multimedia learning. Educational Psychology Review, 14, 87-99.

Muhidin, S.A., \& Abdurahman, M. (2011). Analisis Korelasi, Regresi dan Jalur dalam penelitian. Bandung: Pustaka Setia.

Mousavi, S., Low, R., \& Sweller, J. (2010). Reducing cognitive load by mixing auditory and visual presentation modes. Journal of Educational Psychology, 87, 319-334.

Nashar, H. (2004). Peranan Motivasi \& Kemampuan Awal. Jakarta: Delia Press.

Purwanto. (2010). Evaluasi Hasil Belajar. (Cetakan ke-2). Yogyakarta : PustakaPelajar.

Sudjana, N. (2010). Penilaian Hasil Proses Belajar Mengajar. Bandung: PT Remaja Rosdakarya.

Widianingtiyas, L., Siswoyo, S., \& Bakri, F. (2015). Pengaruh pendekatan multi representasi dalam pembelajaran fisika terhadap kemampuan kognitif siswa SMA. Jurnal Penelitian E Pengembangan Pendidikan Fisika, 1(1), 31-38. 